\title{
Indomethacin treatment for patent ductus arteriosus in very low birthweight infants: double blind trial
}

\author{
P RUDD, P MONTANEZ, K HALLIDIE-SMITH, AND M SILVERMAN
}

Department of Paediatrics and Neonatal Medicine and Department of Cardiology, Royal Postgraduate Medical School, Hammersmith Hospital, London

SUMmARY Thirty very low birthweight (VLBW) infants (mean gestational age 28.9 weeks; mean birthweight $1138 \mathrm{~g}$ ) with symptomatic patent ductus arteriosus (PDA) were entered in a randomised double blind trial of indomethacin treatment. The mean age at diagnosis was $7 \cdot 6$ days and at entry to the trial 10.7 days. Before treatment for PDA the indomethacin and placebo groups were well matched for gestational age, birthweight, incidence of respiratory distress requiring mechanical ventilation, and fluid intake. Treatment was up to three daily doses of indomethacin $0.2 \mathrm{mg} / \mathrm{kg}$ or placebo by gastric tube and fluid restriction. During treatment there was a response in 13 out of 15 in the indomethacin group and in 3 out of 15 in the control group $(P<0.001)$, but because of relapse the effect was maintained in only 7 out of 15 and 2 out of 15 respectively $(P<0 \cdot 05)$. No abnormalities were attributable to indomethacin, which is a safe and effective treatment for PDA in the VLBW infant, but the high relapse rate despite fluid restriction suggests that the best treatment has still to be found.

Patent ductus arteriosus (PDA) complicates the management of between 21 and $62 \%$ of infants with idiopathic respiratory distress syndrome ${ }^{1-4}$ and leads to greater dependency on oxygen therapy and mechanical ventilation and to an increased incidence of bronchopulmonary dysplasia..$^{5}$ Differences in the prevalence of PDA in different populations may be due to several factors, but both retrospective ${ }^{6}$ and prospective ${ }^{7}$ studies have shown that the incidence of PDA is related to the volume of fluid given to the very low birthweight (VLBW) infant.

Indomethacin has been used to treat PDA since the work of Heymann et al., ${ }^{8}$ but there have been very few double blind trials in which its effectiveness has been compared with that of fluid restriction alone. ${ }^{34}$ Since increasing the fluid given to babies in a population increases the incidence of PDA, fluid restriction may play a part in the treatment of this condition. We report a double blind controlled trial of indomethacin in $30 \mathrm{VLBW}$ infants, most of whom were managed on modest amounts of fluid before they developed PDA.

\section{Patients and methods}

Thirty VLBW infants $(<1500 \mathrm{~g}$ at birth) were entered in the trial, which lasted 21 months. They were drawn from a population of 241 infants with birthweights under $1500 \mathrm{~g}$ who were admitted to the neonatal intensive care unit over this period, of whom $34(14 \cdot 1 \%)$ developed classic features of PDA.

Criteria for treatment were a murmur characteristic of PDA and full pulses in the absence of anaemia (defined as a haemoglobin of $10 \mathrm{~g} / \mathrm{dl}$ or less), and at least 2 of the following: active cardiac impulse, loud pulmonary component of the second heart sound, radiographic changes of cardiomegaly (cardiothoracic ratio of 0.6 or more), pleonaemia, and an LA/Ao ratio (ratio of diameters of left atrium and aortic root) on $\mathrm{M}$ mode echocardiography of 1.2 or more. Each baby was assessed before and after treatment by a paediatric cardiologist (KH-S). Four infants who fulfilled the above criteria were excluded, 2 with jaundice (serum bilirubin $>200 \mu \mathrm{mol} / 1 ; 11.7$ $\mathrm{mg} / 100 \mathrm{ml}$ ) because of the possible side effects $\mathrm{cf}$ indomethacin, and 2 who were treated by the attending medical staff before entry into the trial could be arranged. No infant had to be excluded because of thrombocytopenia (platelet count $<80 \times 10^{9} / 1 ; 80000 / \mathrm{mm}^{3}$ ), hyponatraemia (plasma sodium $<120 \mathrm{mmol}(\mathrm{mEq}) / \mathrm{l}$ ), hyperkalaemia (plasma potassium $>6 \mathrm{mmol}(\mathrm{mEq}) / \mathrm{l})$, or necrotising enterocolitis. During the trial plasma and urine urea, 
electrolytes and serum bilirubin concentrations, and platelet counts were measured.

Most babies were nursed under radiant heaters after admission to the ward, and fluid was first given at a rate of about $60-80 \mathrm{ml} / \mathrm{kg}$ a day. Fluid therapy was then adjusted daily to maintain a urine specific gravity of 1003 to 1008 (determined by refractometer: American Optical). After the diagnosis of a PDA fluids were given at a volume which was $20 \%$ less than that of the previous 24 hours. If after a further 24 hours of fluid restriction the infant satisfied the criteria for treatment described above then he or she was allocated blindly at random into either a group for indomethacin treatment or a control placebo group according to a numbered code, so that in each batch of 10 there were 5 indomethacin treated and 5 control babies. Both preparations looked alike and the medical staff did not know what had been given. No patient's code was broken until failure to respond to the trial drug or relapse had occurred, or until the results of each group of 10 babies were analysed.

The drug was given by nasogastric tube and fluid intake was restricted to $60 \mathrm{ml} / \mathrm{kg}$ for 8 hours to compensate for the fall in urinary output associated with indomethacin. ${ }^{9}$ For the next 16 hours fluid intake was increased to that given between the diagnosis of PDA and entry into the trial. The babies were assessed 24 hours after each dose; if the signs had completely disappeared or a murmur was the only sign of PDA no further dose of indomethacin was given and the treatment was deemed to have been successful. A maximum of 3 doses at daily intervals was given. Fluid restriction was continued for 48 hours after the last dose of drug. After a successful response to treatment no more than 150 $\mathrm{ml} / \mathrm{kg}$ a day was allowed for the following week. Neither frusemide nor digoxin were given during the treatment.

Babies who failed to respond to treatment, or who relapsed after completion of the trial were given indomethacin, up to a maximum of 3 doses, on an open basis. When indicated clinically, simple medical management (fluid restriction and frusemide treatment) or surgical closure was carried out.

The comparison between indomethacin and control groups was carried out using $t$ tests or $\chi^{2}$ tests as appropriate.

\section{Results}

The control and treatment groups were similar in most respects on entry to the trial (Table 1), despite the fact that the treatment group was skewed by the inclusion of 2 infants not born in this hospital, one of relatively advanced age (35 days) and the other with excessive fluid intake $(250 \mathrm{ml} / \mathrm{kg}$ a day).
Table 1 Comparison between indomethacin and control groups

\begin{tabular}{|c|c|c|}
\hline & $\begin{array}{l}\text { Control } \\
\text { group }\end{array}$ & $\begin{array}{l}\text { Indomethacin } \\
\text { group }\end{array}$ \\
\hline $\begin{array}{l}\text { Gestational age at birth (wk) } \\
\quad(\text { mean } \pm \text { SD) }\end{array}$ & $29 \cdot 0 \pm 1 \cdot 7$ & $28 \cdot 9 \pm 1 \cdot 2$ \\
\hline Birthweight (g) (mean \pm SD) & $1170 \pm 211$ & $1105 \pm 251$ \\
\hline $\operatorname{Sex}(\mathbf{M}: F)$ & $8: 7$ & $5: 10$ \\
\hline $\begin{array}{l}\text { Born at this hospital : Not born at } \\
\text { this hospital }\end{array}$ & $8: 7$ & $8: 7$ \\
\hline $\begin{array}{l}\text { Age at diagnosis of PDA (days) } \\
(\text { mean } \pm \text { SD) }\end{array}$ & $6 \cdot 8 \pm 3 \cdot 0$ & $8 \cdot 3 \pm 7 \cdot 3^{*}$ \\
\hline $\begin{array}{l}\text { Age on treatment of PDA (days) } \\
(\text { mean } \pm \text { SD) }\end{array}$ & $10 \cdot 2 \pm 5 \cdot 3$ & $11 \cdot 0 \pm 8 \cdot 1^{*}$ \\
\hline Respiratory distress (+ IPPV) & $14(14)$ & $12(11)$ \\
\hline \multicolumn{3}{|l|}{ Mean fluid intake $(\mathrm{ml} / \mathrm{kg})$} \\
\hline $\begin{array}{l}\text { 1-7 days' postnatal age } \\
(\text { mean } \pm \text { SD) }\end{array}$ & $101 \pm 13$ & $100 \pm 28$ \\
\hline $\begin{array}{l}4 \text { days before trial drug } \\
\text { (mean } \pm \text { SD) }\end{array}$ & $116 \pm 29$ & $122 \pm 50 \dagger$ \\
\hline $\begin{array}{l}1 \text { day before trial drug } \\
\text { (mean } \pm \text { SD) }\end{array}$ & $124 \pm 26$ & $124 \pm 47 \dagger$ \\
\hline
\end{tabular}

PDA $=$ patent ductus arteriosus, IPPV $=$ intermittent positive pressure ventilation.

*One patient diagnosed at 31 days and treated at 35 .

†One patient given $250 \mathrm{ml} / \mathrm{kg}$ at referring hospital.

Treatment was successful at first in 13 out of 15 $(87 \%)$ of the indomethacin treated group and in 3 out of $15(20 \%)$ of controls $(P<0.001)$, but because of relapse the long term success rates were 7 out of 15 $(47 \%)$ and 2 out of $15(13 \%)$ respectively $(P<0.05)$. The full 3 day course of treatment was required by only 2 of the 16 early responders, because the others responded after 1 or 2 doses only. Relapses occurred between 1 and 14 days (mean 8 days) after the final dose.

The group of 6 patients who relapsed after an apparently early success in the indomethacin group were examined in greater detail (Table 2). Although they tended to be smaller, of lower gestational age at birth, and younger at the time of treatment than those in whom the response was maintained, no difference was statistically significant. The mean number of doses of indomethacin (1.7) was identical in both groups. It was notable that of babies weighing $<1000 \mathrm{~g}$ at birth, only 1 out of 5 had a successful long term response (although 5 out of 6 improved immediately after treatment), compared with 6 out of 8 heavier infants. Relapse did not occur

Table 2 Indomethacin group: success and relapse

\begin{tabular}{lll}
\hline & Success & Relapse \\
\hline Total No $(<1000 \mathrm{~g})$ & $7(1)$ & $6(4)$ \\
Birthweight $(\mathrm{g})($ mean $\pm \mathrm{SD})$ & $1222 \pm 252$ & $986 \pm 184$ \\
Gestational age (weeks) (mean $\pm \mathrm{SD})$ & $29 \cdot 0 \pm 1 \cdot 4$ & $28 \cdot 3 \pm 0 \cdot 9$ \\
Age at time of treatment (days) & $12 \cdot 6$ & $8 \cdot 3$ \\
No of doses of indomethacin (mean $\pm \mathrm{SD})$ & $1 \cdot 7 \pm 0 \cdot 3$ & $1 \cdot 7 \pm 0 \cdot 8$ \\
Fluid intake (ml/kg a day) (mean $\pm \mathrm{SD})$ & & \\
4 days before treatment & $113 \pm 31$ & $106 \pm 45$ \\
7 days after treatment & $126 \pm 14$ & $114 \pm 26$ \\
\hline
\end{tabular}


Table 3 Results of trial

\begin{tabular}{lll}
\hline & $\begin{array}{l}\text { Control } \\
\text { group } \\
(n=15)\end{array}$ & $\begin{array}{l}\text { Indomethacin } \\
\text { group } \\
(n=15)\end{array}$ \\
\hline Early successful response & 3 & 13 \\
Permanent response & 2 & 7 \\
Relapse & 1 & 6 \\
Failure to respond & 12 & 2 \\
Relapse and failure & 13 & 8 \\
$\quad$ Responded to further indomethacin & $6 / 11$ & $0 / 4$ \\
Closed spontaneously & 4 & 5 \\
Surgical closure & 1 & $2(1$ died) \\
Died before closure & 2 & 1 \\
Complications & 1 & 0 \\
$\quad$ Gastrointestinal bleeding & 2 & 2 \\
Hyponatraemia (serum sodium & & \\
$\quad$ concentration <125 mmol(mEq)/1) & 2 & 2 \\
Death & 2 & \\
\hline
\end{tabular}

simply because of excessive fluid therapy in the days immediately before or after treatment (Table 2).

The patients who relapsed or failed to respond to treatment had a mixed outcome (Table 3). Six of the 11 in the control group responded to indomethacin treatment given on an open basis, whereas none of 4 relapsed patients in the indomethacin group did so. Of the remaining 15 patients with persistent PDA, 9 recovered spontaneously and 3 required surgical ligation of the PDA because of persistent symptoms and failure to thrive. Three patients died before their PDA had closed and 1 died postoperatively. No complications were attributable to indomethacin treatment. The single case of gastrointestinal bleeding (minor gastric haemorrhage) occurred in a control patient. Transient hyponatraemia occurred in 2 out of 15 babies in both groups.

\section{Discussion}

We have shown that intragastric indomethacin (with fluid restriction) was more successful than fluid restriction alone in treating symptomatic PDA in VLBW infants. Moreover, the regimen of up to 3 daily doses of indomethacin $0.2 \mathrm{mg} / \mathrm{kg}$ had no important side effects. Two comparable double blind trials have been reported, one using intragastric indomethacin and the other intravenous indomethacin. ${ }^{34}$ In both the results of treatment were assessed 24 hours after the final dose of the trial drug and no mention was made of a subsequent relapse rate. Our results at 24 hours are almost identical to those reported (Table 4), but we continued to monitor patients for relapse, blind to the nature of their trial drug, and hence our disappointing rate of relapse of 6 of the 13 patients who responded at first to indomethacin. There are several possible reasons for the high relapse rate. Infants weighing less than $1000 \mathrm{~g}$ may be more prone to relapse ${ }^{1011}$ and such infants were certainly over-represented in our relapse group. Another possibility is that fluid restriction during the trial may have led to the disappearance of signs, even though the ductus remained open, and even $M$ mode echocardiography may not be reliable in this case. ${ }^{12}$ This hypothesis seems unlikely, however, since fluid restriction in the control group did not produce a response in an appreciable number of babies, and because reopening of the ductus did not occur until a mean of eight days after the last doseseveral days after fluid restriction had been lifted. Nadas suggested that the duct has to be 'nailed shut' as well as closed, ${ }^{13}$ but unfortunately clinical signs cannot be relied on to distinguish between the two types of response and thereby tell us whether treatment is likely to be successful in the long term.

How may relapse be avoided? Completing the full indomethacin course of 3 doses might have reduced the number of relapses, or intravenous treatment might have been more successful. Intravenous indomethacin used on an open basis in a dose of $0.2 \mathrm{mg} / \mathrm{kg}$ daily has been associated with a relapse rate of only $7 \%, 14$ but there are no reports of the rate of relapse after double blind trials of intravenous administration of the drug. After intravenous treatment drug clearance was faster in nonresponders than in responders, with lower 6 and 24 hour blood concentrations, but clearance in babies whose response has been maintained and those who have gone on to relapse has been similar. ${ }^{14}$ If this had been true of our patients then the high early response rate suggests that the indomethacin must have been adequately absorbed despite the fact that

Table 4 Results of double blind trials of indomethacin in treatment of patent ductus arteriosus (PDA) in preterm babies

\begin{tabular}{|c|c|c|c|c|c|c|c|c|c|c|}
\hline \multirow[t]{3}{*}{ Reference } & \multirow[t]{3}{*}{ Population } & \multicolumn{3}{|c|}{ Indomethacin treatment } & \multicolumn{6}{|c|}{ Response to treatment } \\
\hline & & \multirow{2}{*}{$\begin{array}{l}\text { Dose } \\
(\boldsymbol{m g} / \boldsymbol{k g})\end{array}$} & \multirow{2}{*}{ Route } & \multirow{2}{*}{$\begin{array}{l}\text { Interval } \\
(h)\end{array}$} & \multicolumn{3}{|c|}{ Indomethacin } & \multicolumn{3}{|c|}{ Control } \\
\hline & & & & & No & $24 h^{*}(\%)$ & Later $(\%)$ & No & $24 h^{*}(\%)$ & Later (\%) \\
\hline $\begin{array}{l}\text { Yanagi et al. }{ }^{3} \\
\text { Yeh } \text { et al. }{ }^{4} \\
\text { Present study }\end{array}$ & $\begin{array}{l}\text { Preterm; RDS + IPPV } \\
<2040 \text { g at birth } \\
<1500 \text { g at birth }\end{array}$ & $\begin{array}{l}0 \cdot 2 \\
0 \cdot 3 \\
0 \cdot 2\end{array}$ & $\begin{array}{l}\text { Intragastric } \\
\text { Intravenous } \\
\text { Intragastric }\end{array}$ & $\begin{array}{l}8-24 \\
24 \\
24\end{array}$ & $\begin{array}{l}21 \\
28 \\
15\end{array}$ & $\begin{array}{l}81 \\
89 \\
87\end{array}$ & $\begin{array}{l}+ \\
\dagger \\
47\end{array}$ & $\begin{array}{l}18 \\
27 \\
15\end{array}$ & $\begin{array}{l}28 \\
22 \\
20\end{array}$ & $\begin{array}{l}\dagger \\
\dagger \\
13\end{array}$ \\
\hline
\end{tabular}

*Assessed 24 hours after final dose.

†Data not available.

RDS $=$ respiratory distress syndrome, IPPV = intermittent positive pressure ventilation. 
most infants were not receiving enteral feeding at the time of the study. The reason for relapse is obscure, and this probably could not have been prevented either by intravenous indomethacin or by measuring blood concentrations.

The low rate of symptomatic PDA among VLBW infants in our unit $(14 \%)$ may perhaps be due to our restrictive regimen of fluid management, and in particular to the careful measurement of urinary specific gravity by refractometer, so that fluid intake is kept to the minimum required for healthy fluid balance over the first 2 weeks of life. Under more liberal conditions of fluid therapy, Bell et al. ${ }^{7}$ found an association between fluid intake and PDA. We were unable to show an important difference between the fluid volume given to babies in our study before the development of PDA and matched controls who did not develop PDA. Of 13 babies whose PDA was diagnosed after 7 days of age, mean fluid intake over the first 7 days was $103 \pm 16 \mathrm{ml} / \mathrm{kg}$ (mean \pm SD) compared with $110 \pm 22 \mathrm{ml} / \mathrm{kg}$ (mean $\pm \mathrm{SD}$ ) in 13 controls matched for gestational age, birthweight, and presence of respiratory disease.

Few authors have reported the fluid intake before the development of PDA, but Stevenson ${ }^{6}$ quoted a mean of $153 \mathrm{mg} / \mathrm{kg}$ a day in babies developing this condition. In one centre excessive fluid intake in early postnatal life may have led to an incidence of PDA, high enough to justify a trial of prophylactic indomethacin. ${ }^{16}$ Perhaps a more rational approach would be to limit fluid intake and thereby reduce the overall incidence of PDA. Then, other factors responsible for maintaining the patency of the ductus arteriosus may be identified.

Because of the results of the trial we have slightly modified the management of PDA. Although the fluid management of babies both before and after the development of PDA is unchanged, a full 3 dose course of indomethacin is given to all babies who require treatment in the hope that this may reduce the number of relapses that occur after the apparent success of one or two doses of the drug.

We thank the many members of staff who helped us during the trial, particularly Dr Deborah Hodes.

\section{References}

1 Cotton R B, Stahlmann M T, Kovar I, Catterton W Z. Medical management of small preterm infants with symptomatic patent ductus arteriosus. J Pediatr 1978; 92 : 467-73.
${ }^{2}$ Siassi B, Blanco C, Cabal L A, Coran A G. Incidence and clinical features of patent ductus arteriosus in low birthweight infants. A prospective analysis of 150 consecutively born infants. Pediatrics 1976; 57: 347-51.

3 Yanagi $R$ M, Wilson A, Newfeld E A, Aziz K U, Hunt C E. Indomethacin treatment for symptomatic patent ductus arteriosus: a double blind control study. Pediatrics 1981; 67: 647-52.

4 Yeh T F, Luken J A, Thalji A, Raval D, Carr I, Pildes $R$ S. Intravenous indomethacin therapy in premature infants with persistent ductus arteriosus-a double-blind controlled study. J Pediatr 1981; 98: 137-45.

5 Merritt T A, Harris J P, Roghmann K, et al. Early closure of the patent ductus arteriosus in very low birthweight infants: a controlled trial. $J$ Pediatr 1981; 99: 281-6.

6 Stevenson J G. Fluid administration in the association of patent ductus arteriosus complicating respiratory distress syndrome. J Pediatr 1977; 90: 257-61.

7 Bell E F, Warburton D, Stonestreet B S, Oh W. Effect of fluid administration on the development of symptomatic patent ductus arteriosus and congestive heart failure in premature infants. $N$ Engl J Med 1980; 802: 598-604.

8 Heymann M A, Rudolph A M, Silverman N H. Closure of the ductus arteriosus in premature infants by inhibition of prostaglandin synthesis. $N$ Engl J Med 1976; 295: 530-3.

9 Friedman W F, Hirschklau M J, Printz M P, Pitlick P T, Kirkpatrick S E. Pharmacologic closure of patent ductus arteriosus in the premature infant. N Engl J Med 1976; 295: 526-9.

10 Ivey H H, Kattwinkel J, Park T S, Krovetz L J. Failure of indomethacin to close persistent ductus arteriosus in infants weighing under 1000 grams. Br Heart $J 1979 ; 41$ : 304-7.

11 Obeyesekere H I, Parkhurst S, Yu V Y H. Pharmacological closure of the ductus arteriosus in preterm infants using indomethacin. Arch Dis Child 1980; 55: 271-6.

12 Valdes Cruz L M, Dudell G G. Specificity and accuracy of echo-cardiographic and clinical criteria for diagnosis of patent ductus arteriosus in fluid restricted infants. $J$ Pediatr 1981 ; 98: 298-305.

13 Nadas A S. Indomethacin and the patent ductus arteriosus. $N$ Engl J Med $1981 ; 305$ : 97-8.

14 Brash A R, Hickey D E, Graham T P, Stahlman M T, Oates J A, Cotton R B. Pharmacokinetics of indomethacin in the neonate. Relation of plasma indomethacin levels to response of the ductus arteriosus. $N$ Engl J Med 1981; 305: $67-72$.

15 Harris J P, Merritt T A, Alexson C G, Longfield L, Manning J A. Parenteral indomethacin for closure of the patent ductus arteriosus. Clinical experience with 67 preterm infants. Am J Dis Child 1982; 136: 1005-8.

16 Mahony L, Carnero V, Brett C, Heymann M A, Clyman R I. Prophylactic indomethacin therapy for patent ductus arteriosus in very low birthweight infants. $N$ Engl J Med 1982; 306: 506-10.

Correspondence to Dr M Silverman, Department of Paediatrics and Neonatal Medicine, Hammersmith Hospital, Du Cane Road, London W12 0HS.

Received 11 January 1983 